\title{
Synopsis of the Determinants of the Choice of a Financial Structure of French Industrial and Commercial Groups
}

\author{
Assoumou Menye Oscar \\ Department "Finance and Accounting", ESSEC of the Douala University, Douala, Cameroon \\ Email address: \\ oscar_assoumou@yahoo.fr, oscar.assoumou@gmail.com \\ To cite this article: \\ Assoumou Menye Oscar. Synopsis of the Determinants of the Choice of a Financial Structure of French Industrial and Commercial Groups. \\ Journal of Finance and Accounting. Vol. 9, No. 4, 2021, pp. 172-181. doi: 10.11648/j.jfa.20210904.17
}

Received: August 17, 2021; Accepted: August 27, 2021; Published: August 31, 2021

\begin{abstract}
Belonging to a group modifies the financing conditions of the firms concerned. Thus, we observe that the conditions of access to the financial markets are modified by the very fact of belonging to a group whose financial surface is the most easily identifiable; the interest rates on the loans themselves are less high for these companies. Their dependence on the banking system also appears to be less clear-cut, as the group's head company is able to pass on loans negotiated on favourable terms to certain units within the group. With regard to the level of debt alone, there is often reference to a higher level of debt in groups, based on the chain accounting of the same asset, first as fixed assets and then as equity securities. This last point raises the question of the choice of relevant levels of aggregation for measuring financial variables. Until now, most studies have been based on data from the company accounts. However, the consolidated financial statements provide a better assessment of the financial situation of these groups, in particular by eliminating fully or proportionally consolidated investments. In order to gain a better understanding of the level of indebtedness of a group, it is more appropriate to use the consolidated financial statements to eliminate cross-financing for companies included in the scope of consolidation. Using such data, we can observe real divergences with the results of studies on corporate accounts, which show more favorable borrowing conditions, slightly lower levels of debt and a clear decrease in the use of borrowing in the financing resources for the period 2017-2020, with a domination of self-financing. These divergences can also be observed when comparing the debt levels of companies in different countries where the practice of consolidation is more or less widespread. The main objective of this article is to present the results, obtained from a sample of consolidated accounts of French industrial and commercial groups, of a modeling of debt levels put in perspective with modern financial theory, in that it proposes conceptual candidates explaining current developments.
\end{abstract}

Keywords: Group, Indebtedness, Financing, Interest Rates, Consolidated Accounts, Corporate Accounts, Profitability

\section{Introduction}

In order to remain or become viable, most large companies establish all sorts of industrial, commercial and financial relationships, which may be limited to a single field (research and development, for example), or may be global or even heterogeneous. It is important to study the policies of groups of companies, particularly with regard to financing.

Belonging to a group will modify the financing conditions of the companies concerned. Thus, we observe that the conditions of access to financial markets are modified by the very fact of belonging to a group whose financial surface is the most easily identifiable; the interest rates on loans themselves are lower for these companies. Their dependence on the banking system also appears to be less clear-cut, as the group head company is able to pass on loans negotiated on favourable terms to certain units of the group. As regards trade credit, the hypothesis of "support" behaviour through customer credit is also put forward $[4,9,12]$.

With regard to the level of debt alone, there is often reference to higher levels of indebtedness on the part of groups, an assumption based on a chain of accounting for the same asset: first in fixed assets, then in equity securities ${ }^{1}$. This last point raises the question of the choice of relevant levels of aggregation for measuring financial variables. Until now, most studies have been based on data from the company

1 On this question, see Richard, Simons, Bailly [1988]. 
accounts. However, the consolidated financial statements provide a better assessment and understanding of the financial situation of these groups, in particular by eliminating fully or proportionally consolidated investments ${ }^{2}$. In order to obtain an overall assessment of the level of indebtedness of a group, the use of consolidated accounts seems necessary in order to eliminate cross-financing for the companies included in the scope of consolidation. Using such data, one can observe real divergences with the results of studies on corporate accounts, which show in particular more favorable borrowing conditions, slightly lower levels of debt and a recourse to borrowing in the resources the financing mix for the period 2017-2020 is clearly decreasing, with selffinancing $[9]^{3}$ dominating. These differences can also be observed when comparing the debt levels of companies in different countries where the practice of consolidation is more or less widespread; for example, the differences usually observed in debt levels between French and American companies are less clear-cut when using consolidated accounts (for listed companies) than with other types of accounting sources $[37]^{4}$.

The main objective of this article is to present the results obtained from a sample of consolidated accounts of French industrial and commercial groups, of a modeling of debt levels put in perspective with the whole of modern financial theory, in that it proposes conceptual candidates explaining current developments. In the first section, we will attempt to specify both the empirical context and the theoretical stakes of a study on the indebtedness of groups in order to present in a synthetic manner the testable hypotheses relating to the indebtedness of industrial and commercial groups. The second section presents the results of the modeling of group debt levels. In this regard, it should be noted that until now, there are few studies in France on the determinants of financial structures, where the validity of the main theoretical models is tested $[5,36]^{5}$. The main objective of this contribution is to fill this gap by proposing a taxonomy of groups and the determinants of their financial structure.

\section{Theoretical and Empirical Contexts}

It seems useful to us to clarify two aspects beforehand. First, the context in which the question of groups arises in financial management and how the specificity of this approach modifies the understanding of the problem of indebtedness. On the other hand, what elements of financial theory should be used to analyse group indebtedness? We will address these two considerations in turn.

\footnotetext{
2 See Malécot [1991] and Malécot [1992b].

3 Hélène CHARASSON-JASSON, " The growing recourse of large French groups to debt: a financing strategy that shows its limits, Bulletin de la Banque de France n ${ }^{\circ} 226-4$, November 2019.

4 See Remolona (1990).

5 We refer in particular to Dubois [1988], Biais, Hillion and Malécot [1991], Elisabeth Paulet (2003).
}

\subsection{The Empirical Context}

Three facts should be emphasized: divestitures and acquisitions; increasingly centralized financial management methods; and increasingly multinational financial markets and shareholders.

\subsubsection{Divestitures and Acquisitions}

In France and in Europe, the pace of mergers and acquisitions accelerated sharply in the early 1980s. According to the reports on competition policy drawn up by the European Commission $[11,24]^{6}$, the number of takeovers by the top 1,000 industrial firms in the EEC was 155 in 1983, 208 in 1985, 227 in 1986, 303 in 1987, 383 in 1988 and 492 in 1989, i.e., a near quadrupling between 1983 and 1989. The prospect of the single market was not unrelated to this acceleration, but this movement is part of a general trend that can be traced back to the second oil crisis [1] .

If the concentration of the productive apparatus resulting from this movement already appears strong when measured at the level of each country in terms of turnover or number of employees, financial concentration (with the amount of equity capital involved as an indicator) was even clearer in the early $1990 \mathrm{~s}^{8}$. However, since the 2000s, the trend has been slowing down with the relocation of companies and, above all, with the emergence of China and other newly industrialized countries. This financial aspect of the movement can be explained, among other factors, by the recent rise in profits, by the general expansion of financial markets and their growing interconnection (thanks to the computerization of operations, the digitization of information and telematic transmissions) and the multiplication of financial innovations.

It should be noted that a double movement is in fact taking place: there are merger-absorption operations that lead to the regrouping of companies whose activities are different in nature (diversification approach); but there is also a tendency to recompose or share activities, which on the other hand results in the sale of previously linked entities (refocusing approach) $[7,8,21]^{9}$. We know that these two types of group strategies currently exist [3 $]^{10}$. In terms of group resources, it should be noted that asset disposals promote financial flexibility; in the event of financing needs not being met by external resources, the disposal may in fact make it possible to finance operations considered more essential ${ }^{11}$.

\subsubsection{Centralization of Financial Management}

The study of the determinants of indebtedness at the level

6 Refer to de Laet [1991].

7 See Amar, Thollon-Pommerol [1989], Malécot [1992a].

8 Morin [1991].

9 Cathiard C. Lecourt A., The practice of European company law. Comparative analysis of cross-border structures and mergers, Joly Editions, 2nd edition, 2017; Chadefaux M., Company mergers: Legal and tax regimes, 8th edition, Groupe Revue Fiduciaire, 2016; Hege U., Lovo S., Slovin M., "Equity and cash in intercorporate asset sales: theory and evidence", Review of Financial Studies, February 2009, vol. 22, ${ }^{\circ}$ 2, pp. 681-714.

10 See Thollon-Pommerol [1990] and Batsch [1992].

11 This is what can be observed empirically for groups using consolidated accounts. 
of groups, using consolidated accounts, offers a major interest, that of matching the information and the accounting measurement of the financial phenomenon with the reality of the group's financial management.

Indeed, over the last thirty years, we have seen the emergence of a genuine global financial planning process at the level of most large groups. This is easily explained. How, for example, can interest rate risk be managed without relatively detailed forecasting at the level of the group as a whole, detailing in particular intra-group financial flows and providing an estimate of the group's financial structure?

In addition, many groups have set up specialized and concentrated units, usually close to headquarters, which are mainly, but not exclusively, responsible for cash management, both for the investment of liquid assets and for borrowings. They work closely with the banks' trading rooms. The very concept of treasury today is necessarily centralized because it must integrate all the group's operations. Some of these divisions can truly be described as group banks (Ohana [35]). This integration now goes much further than it did in the past for the sole purpose of hedging foreign exchange risks, which already required the measurement of a foreign exchange position. The evolution of the banking system itself is moving in the direction of further concentration if the group wants to compete. Many group treasury and financing departments are defining a global banking policy that consists of determining the number of banks with which it is appropriate to work and in relation to which types of products. In most cases, bankcompany negotiations are bilateral, as the practice of pooling banks does not allow for competition, according to the groups' finance departments.

\subsubsection{Internationalization of Markets and Shareholders}

Similarly, we know that the financial markets are increasingly attentive to the publication of consolidated results, which are subject to periodically revised forecasts for the largest listed groups. Almost all industrial and commercial companies listed on the Paris stock exchange are part of a group, or belong to a group, of which they are the head. In addition, the responsibilities of the financial departments of each group with respect to their shareholders, who are increasingly multinational, and whose information needs must be satisfied in accordance with the reference accounting standards [39] ${ }^{12}$ (IFRS, IASC, SEC, etc.), must be mentioned. This is a real imperative if one wants to take advantage of one's size to raise capital on several national financial markets. Finally, as groups often resort to external growth or to the sale of entities, they have given rise to financial engineering, which is legal in nature, and to equity strategies, which are once again highly concentrated at the level of the head of the group.

Many of the traditional elements of financial management must now be studied at the group level $[42]^{13}$. Thus, size is becoming an even more discriminating factor in the cost of

12 Robert Obert, Le Petit IFRS 2020, Dunod, 11th Edition, February 2020 13 Vernimmen, 2021, chap. 48, pp. 993-1013. credit (Conseil National du Crédit), as very large companies have been more inclined to use the commercial paper market than the bond market since 1983. They can thus benefit from rates closer to those of the money market, whereas companies, even large ones, depend a little more on interbank rates, and even for medium-sized companies on rates still close to the bank prime rate $[12,14]^{14}$; the conditions of access to the financial markets insofar as they are related to size thus establish a sort of hierarchy of financing conditions. In addition, with regard to inter-company credit, it has been shown that companies make redistributions and arbitrations between the different companies according to their needs. As regards intra-group financing, group loans are also a significant component of the financing of partner companies: the work of the "Conseil National du Crédit" on the cost of credit shows moreover that the costs of external contributions are lower when they are compared to the costs of non-group and associated contributions (a one point difference on the median interest rate appears in their favour). It is easy to imagine the company, as the head of the group, obtaining financing on more favorable terms, on the commercial paper market for example, and passing it on to the various components of the group.

Taking into account the financial links between companies is therefore an important factor in better understanding the fundamental determinants of financial structures, in relation to the strategic entity that gives it its full meaning. Until now, this consideration has been carried out mainly through the study of shareholdings and financial links, with a possible linkage of the corporate accounts between them [4] ${ }^{15}$. The consolidated financial statements have not yet been widely used for this purpose.

\subsection{Theoretical Background}

If we refer to financial analysis manuals, the first question that arises concerns the group's debt capacity, which would be greater than that of a large company because of the double accounting of a subsidiary's assets, first as fixed assets and then as equity investments. As a result, groups should be more highly leveraged than other companies [42] ${ }^{16}$. This aspect deserves a thorough examination, but it will be difficult to give a precise answer, because, assuming that it is possible to affirm that groups are "over-leveraged", how can we show whether this is related to the principle of double accounting or to the size, the more favourable financing conditions or the lower risk presented by a group because of the diversification of its activities?

However, if this argument seems empirically unfounded $[13]^{17}$, it is also without theoretical validity because it presupposes a profound irrationality of the firm's creditors, banks and financial markets. It is in fact the opposite effect

14 See Dietsch [1990].

15 See in particular Thollon-Pommerol [1990] and Beau [1990].

16 Pierre Vernimmen, Corporate finance, Dalloz, 19th edition, 2021, chapter 41.

17 Denis D., Mihov V., "The Choice among bank debt, non-bank private debt and public debt: evidence form new corporate barrowings", Journal of Financial Economics, January 2003, n ${ }^{\circ}$, vol. 70, pp 3- 28. 
that one would expect. Indeed, if the creditor is in a situation of asymmetric information concerning the firm's real assets, he will be inclined to ration debt. Gradually, these various reservations should naturally lead to the observation of a lower level of indebtedness of groups. Or to ask for additional information, in a way seeking an optimal balance between the contribution of this in-depth information and the additional costs of investigation $[19]^{18}$. The creditor may also request broader coverage of its risks by seeking a guarantee or surety from the parent company.

What are the main determinants of corporate financial structures and how can we test their validity and relevance at the group level? The null hypothesis in this area is represented by the theorems of Modigliani and Miller, namely that debt rates are randomly distributed. Against this null hypothesis, there are essentially six main determinants that we will examine in turn: taxation, asymmetric information, the segmentations of financial markets linked to the size of the firm, growth and future opportunities.

\subsubsection{Taxation}

This is an old consideration, based on the argument that financial costs relating to interest on loans are deductible from taxable income. The effective cost of debt may therefore appear, in a situation of certainty, to be reduced according to the firm's effective tax rate. Since shareholder remuneration is not generally subject to the same tax treatment (with the exception of certain cases of very limited application, such as the deductibility of dividends in the case of a cash capital increase), firms may have an interest in debt. Conversely, the presence of tax deductions not explicitly linked to debt would allow firms to make certain deductions that limit the specificity of debt. According to De Angelo and Masulis [2], we should then observe that firms that have a high capacity for tax deductions (depreciation, provisions, tax credits) relative to their expected profitability have a lower debt ratio [26] ${ }^{19}$. The disadvantage of such prescriptions is that they are difficult to translate empirically, since it would be necessary to be able to measure, at the level of depreciation or provisions, what is economically motivated (the wear and tear on capital or a potential loss), and thus to estimate the residual.

In the case of groups, it is even more difficult to obtain measures of these deduction capacities because transfer prices between group companies can easily be used to manage the tax benefits of each entity. However, these transfer prices are of course not observable in the consolidated accounts (Richard, Simons, Bailly, 1988) [38]. Moreover, since the consolidated accounts are drawn up in accordance with the principle of tax transparency, we are not able to observe any more information than in the company accounts concerning the importance of the tax motivation.

18 Harris and Raviv [1990].

19 Lonnidou V., Ongena S., "Time for a change: loan conditions and bank behavior when firms switch banks", Journal of Finance, October 2010, vol. 65, n ${ }^{\circ} 5$, pp. 1847-1877.

\subsubsection{Information Asymmetry}

In this respect, several theoretical arguments can be put forward. First, the hierarchy of financing [34] ${ }^{20}$ : the managers of a firm have a better assessment than its external partners of the real profitability of their current, and especially future, investment projects. Consequently, all external partners, whether creditors or potential new shareholders, are likely to underestimate these capacities. The firm is therefore led, if it wants to mitigate the resulting rationing, to finance its projects primarily with its own internal self-financing resources $[6]^{21}$. If this is not enough, it will then resort first to debt, if it can provide sufficient guarantees, and lastly to an increase in equity. Moreover, as the potential new shareholder does not have any decisive elements on which to base his evaluation of the share, he will ask for a premium to buy the share; this being to the detriment of the former shareholders, the managers who would act in their favour would then be led to abandon certain investment projects. Moreover, concerning the "signal" emitted during a capital increase would therefore be negative, which is related to the abnormal returns observed on the markets at these times ${ }^{22}$.

The "signal" emitted during a capital increase would therefore be negative, which is to be put in relation with the abnormal returns observed on the markets at these times. Conversely, the issuance of debt would be considered as a signal sent to the market by a "good quality" firm. Recent theoretical $[17,22]^{23}$ work has extended this problem. In particular, it is now assumed that the presence of a financing hierarchy is closely linked to the possibility of a deficient (or non-optimal) incentive system, which can be corrected by the drafting of debt contracts incorporating adequate remuneration systems: in this case, the hierarchy is closely linked to the dominant presence of unlisted debt securities on the liabilities side, which is indeed the situation in France $[5]^{24}$.

It is therefore to be expected that the financial structures are inversely related to the importance of self-financing in relation to the projects to be undertaken. The main difficulty is to distinguish between the profitability effect (an increase in self-financing may be due to better profitability, reducing needs) and information effects.

In this respect, the information needs (for a large firm) can be measured by dividend payments $[42]^{25}$. Considered as income for individuals (the dividends of a group are in fact mostly paid to the shareholders of the head company of the group), they are subject to unfavorable taxation, compared to the taxation of capital gains. Thus, the fact of paying

20 Or "Pecking order theory" according to Myers and Majiuf [1984].

21 Brounen D., Jong (de) A., Koedijk K., "Corporate Finance in Europe: confronting theory with practice", Financial Management, vol. 33, n` 4, 2004, pp. $167-184$

22 See the COB report on the secondary market [1992].

23 Holland D., "An improved method for valuing mature companies and estimating terminal value", Journal of Applied Corporate Finance, vol. $30, \mathrm{n}{ }^{\circ} 1$, 2018, pp. 70-77; see also Fernandez P., Valuation and common sense, 7th Edition, 2019 to download from ssrn.com

24 See Biais, Hillion and Malécot [1991].

25 See Malécot [1992d]. See Vernimmen [2021]. 
dividends can be a vector of information vis-à-vis the outside world and thus be an indicator of relative asymmetry of information. Thus, the higher the ratio of dividends to cash flow, the more it indicates a significant asymmetry of information, which obliges the firm to devote a significant fraction of its resources to making up for it, possibly to the detriment of an optimal investment policy, and the more one can expect the debt ratio to be negatively related to it.

Moreover, the balance of current cash flow with industrial investment and dividends paid, the latter two variables being measured over the past few years, is a good indicator of the firm's ability to follow a prioritized financial policy: the higher the balance, the more the firm can be assumed to keep its commitments to undertake only positive net present value investment projects (the hypothesis of maximizing the firm's value) while developing information vis-à-vis the market, and the more resources it has at its disposal to avoid resorting to debt $[16]^{26}$. Conversely, an equally acceptable hypothesis, in line with Jensen's free cash flow theory, is that the amount available would be an indicator of the room for manoeuvre likely to require greater control by the market; since debt is clearly a means of control, it is conceivable that the direction of the relationship between this variable and debt would be reversed. It should be noted, however, that the measure of free cash flow is not quite the one that fits our description, in that instead of using the past average of the variables of dividends and (industrial) investments, it would be necessary to measure the level of investment required to maintain a rate of return identical to that generated by the current assets.

The two measures we have just indicated do not overlap insofar as the first reflects the asymmetry vis-à-vis current shareholders, who actually receive dividends, and the second, the other agents concerned, potential new shareholders or creditors.

\subsubsection{The Costs of Financial Distress}

Traditionally, the idea has often been put forward that the potential costs of financial distress (notably in the event of an inability to repay a loan on time, which generates renegotiation costs), could offset the tax advantage of debt, determining in a way an optimal capital structure. But their theoretical influence is still a matter of debate in the literature. On the other hand, one must agree that their empirical measurement remains imprecise and limited. Indeed, it is important to know what types of costs are being discussed $[20]^{27}$ : if they are liquidation costs, then the results of empirical studies converge in holding them to be a deterrent to increased recourse to debt if the risk is not zero ${ }^{28}$.

Moreover, a firm with highly specialized assets would be likely to incur higher bankruptcy or liquidation costs insofar as any resale or attempt at realization would be made impossible by the non-existence of a resale market for this

26 See Fazzari, Hubbard and Petersen [1988].

27 See mainly Haugen and Sembet [1978].

28 See Malécot synthesis [1992c) for a study with one of the results already obtained on this question. type of asset $[41]^{29}$.

Also in light of what was discussed in our introduction, financial structures should be a function of the value of the fixed assets, as these represent the easiest medium for taking collateral. On the other hand, if we assume that there is a debt overcapacity specific to the group, this link should be of little significance.

\subsubsection{Conflicts of Interest and Control Difficulties}

Several authors in financial theory $[25]^{30}$ believe that the risk of conflicts between managers and creditors is also an important element explaining debt levels. Indeed, once debt has been contracted, the firm may consider modifying its projects at the risk of harming the interests of creditors. For example, in the case of groups, they have the possibility, through sales and acquisitions, of modifying their type of activity quite rapidly and quite extensively. There would therefore be a risk of substitution of the group's assets, which would lead creditors to reduce their assistance in relation to it. This risk would be all the greater the higher the level of indebtedness and the higher the level of equity and securities on the assets side. Conversely, it could be argued that indebtedness is a means of control for the firm, which must periodically have its accounts examined at each new request for financing. A debt that is oriented towards the short term would possibly satisfy such a constraint. Substitution risk can be measured by the percentage of equity and equity-related securities in the balance sheet total.

In the case of groups, a dilution of the role of shareholdermanagers can be noted. In this case, according to Jensen and Meckling [23], creditors may lend less, as control of the group is then less easy.

\subsubsection{Industrial Assets and Size}

The idea that indebtedness is related to the type of activity of the firm, and therefore to the risk linked to the ownership of a particular type of asset, is an old one. It is in part one of the foundations of classical financial analysis, which bases some of its rules of analysis on the adjustment of the terms of assets and liabilities (for example, the long term of liabilities first finances the long term of assets).

The sector can also represent a global and synthetic indicator of the risk linked to the firm's main activity. The work of Miller [1988] supports this idea. However, a number of recent theoretical studies have qualified the supposed link between business risk and the debt ratio. It is said to be largely non-linear, first positively related to debt, then negatively related above a certain level of risk. It should be noted that in the case of groups, where intersectoral diversification is de facto more or less developed, and where at least the number of activities carried out by the firms in the group is certainly not unitary, the possible observation of such a relationship, which is often observed in the United

29 Titman [1984].

30 Krishaswami S., Subramaniam V., "information asymmetry, valuation and corporate spin-off decision”, Journal of Financial Economics, vol. 53, n 1,1999 , pp. 73-112. 
States, will remain without direct interpretation since it will be too aggregate a measure.

The size of the firm, as already mentioned, is also a determining factor in financing conditions. It is also related to the existence of segmented financial markets, where only the largest firms can really benefit from all the possibilities offered. However, it is possible that size is not a sufficient element to discriminate between groups, insofar as most of them have access to all financing possibilities. It is in studies where the diversity of the sample is greater that this aspect may play a role.

\subsubsection{Growth and Profitability}

The presence of growth opportunities plays a role insofar as such opportunities will lead the firm to moderate its current indebtedness in order to be in a position to seize them later. This observation has often been successfully tested, provided that one has adequate stock market information (or proxy variables as with Tobin's average Q). Profitability, on the other hand, has an ambiguous influence: it improves the borrowing capacity of the firm, which is considered to be of better quality than others, and therefore more secure, and it allows the firm to borrow less, for a certain level of investment. According to the first effect, it contributes to increasing indebtedness; according to the second effect, it acts in favor of less indebtedness.

Moreover, profitability can be related to financial expenses. Some models of the risk of default use ratios such as "financial expenses" over "operating profitability". But the risk of default is low in the case of groups, even if it is not zero.

In addition, it seems conceivable that very high-growth groups will have higher debt levels than other groups with moderate growth. However, in the case of consolidated groups and accounts, it is to be expected that during a period of restructuring, growth will be very strong from one year to the next. The growth rate would thus lose its meaning.

\section{Modeling the Determinants of Debt Levels}

The results in this section will focus exclusively on the 2019 data from a larger sample: 161 industrial and commercial groups (the sample is in fact rolled up from 2017 to 2019 in order to be able to measure certain variables with $\left.\operatorname{lags}^{31}\right)$. Prior to this, we had approximately 240 groups, with a total of more than five million employees, and an average of 20,000 employees per group. Compared with the ThollonPommerol classification, the groups in our sample are more of an "intermediate" type. In reference to the first two hundred European groups, the groups in our sample are half the size [40].

First, we will justify the measures of the variables mentioned above. Growth is a variable that often appears as an explanation for a higher level of debt: the stronger the

31 The exploitation of the conditions for obtaining such a sample and its characteristics can be found in Malécot [1991]. growth, the greater the financing needs. However, in the case of groups, this growth is very strong, due to the concentration movements that we have already noted are sustained over the study period. In this respect, table 1 shows the growth data for the sample.

The figures in Table 1 show that the average growth rate is around $20 \%$ if we look at value added or sales in 2018 and 2019. However, the fluctuation is more pronounced for 2019 due to the distorting effects of the covid-19 pandemic and if growth is measured by total assets. The effect of the consolidated accounts is fully felt here: external growth and restructuring policies allow very high average growth rates and a very strong diversity from one group to another.

Table 1. Growth rates by different variables.

\begin{tabular}{|c|c|c|c|c|}
\hline Years & Mean & Standard & Minimum & Maximum \\
\hline \multicolumn{5}{|c|}{ Growth measured by total assets } \\
\hline 2018 & 1,21 & 1,33 & 0,52 & 3,54 \\
\hline 2019 & 1,43 & 1,42 & 0,52 & 12,66 \\
\hline \multicolumn{5}{|c|}{ Growth measured by value added } \\
\hline 2018 & 1,27 & 0,96 & $-0,46$ & 8,56 \\
\hline 2019 & 1,24 & 0,72 & $-2,47$ & 6,24 \\
\hline \multicolumn{5}{|c|}{ Growth measured by revenue } \\
\hline 2018 & 1,29 & 0,92 & 0,19 & 9,77 \\
\hline 2019 & 1,23 & 0,64 & 0,00 & 7,70 \\
\hline
\end{tabular}

Two aspects, usually found in statistical studies of corporate accounts, are not taken into account in this analysis: taxation and inter-company credit. From an epistemological and heuristic point of view, we felt that consolidated accounts were not the best tool for analysing these issues.

The coverage ratio is an indicator of the degree to which operating profitability is able to cover financial expenses, and is therefore an indicator of profitability which, if it expresses a constraint, should be inversely related to the evolution of the debt ratio. This is our hypothesis. Profitability has also been measured, excluding aspects related to financial charges, by the margin rate, i.e. the ratio of gross operating income to sales.

It is the ratio of dividends paid to cash flow that measures the degree of information asymmetry. The dividends paid out at group level are mostly paid to the shareholders of the parent company. In line with the usual assumptions, the dividend is considered as a signal of the company's profitability: the fact that it has to be paid, taking into account the tax costs for the shareholders, indicates that there is an asymmetry of information between the financial markets and the company $[10]^{32}$. A good indicator is therefore the ratio of dividends paid to cash flow for the year. Moreover, as already indicated above, the balance of current cash flow with industrial investments on the one hand, and dividends paid on the other, the latter two variables being measured over the past two years (these are simply averages), is our indicator of the firm's ability to follow a prioritized

32 Chava S., Purnanandam A., "Determinant of the floating-to- fixed rate debt structure of firms", Journal of Financial Economics, vol. 85, ${ }^{\circ} 3$, September 2007, pp. 1-5. 
financial policy.

Financial distress costs are measured by the ability to take real estate collateral, which is considered a more satisfactory return in case of bankruptcy. Indeed, most loans, especially bank loans, are secured by the company's assets: the greater the assets to be secured, the greater the debt. This is the assumed link between the two variables. This variable is measured by the ratio of fixed assets to total assets. If the debt ratio is strictly a function of this ratio, we will have a good indicator for rejecting the hypothesis of overindebtedness of groups in relation to the cascade of holdings between the subsidiary that holds the asset and the parent company: if the debt ratio is greater than the capacity to take on collateral (the case of over-indebtedness), then the link between the collateral ratios and the debt ratio will be weak.

Conflicts of interest and control difficulties are measured by the substitution risk represented by the proportion of equity investments, equity-accounted investments and the amount of marketable securities (all of which is related to the balance sheet total). This is a measure of the risk of substitution of one asset for another. This risk is greater if the asset is in equity securities or in negotiable and liquid securities.

Table 2. APE codes and industry groupings by activity codes.

\begin{tabular}{ll}
\hline Name of the grouping & Activity codes \\
\hline Energy & 05060708 \\
Production of intermediate goods & 10111213141516172021505253 \\
Manufacture of capital goods & 2426272829303132333448 \\
Press Publishing & 51 \\
Building and civil engineering & 55 \\
Production of consumer goods & 18193536373940414445464749 \\
Services Tourism & 676971727375777980818654 \\
Distribution Shops & 57585960616263646590 \\
Miscellaneous & 768789 \\
\hline
\end{tabular}

Usually, the size and the sector of activity are examined. It is important to note, on the one hand, that the firms analyzed in our samples are large firms; on the other hand, that their assets are relatively diversified, even if we have selected groups with a dominant main activity. Given the activity codes available to us, we have roughly grouped the initial sectors into seven general sectors. The definitions of these sectors are given below.

In Table 2, we find the first two digits of the APE codes divided into nine sectors, defined according to their relative economic homogeneity. In Table 3, we have grouped them into seven sectors, the seventh being the service sector considered as a whole. Subsequently, we have retained only seven distinct sectors, defined in Table 3.

Table 3. Sector Breakdown.

\section{Sector 1: Energy}

Sector 2: Intermediate Goods

Sector 3: Capital goods

Sector 4: Press, Publishing, Telecoms, Internet

Sector 5: Construction, Civil Engineering

Sector 6: Consumer goods

Sector 7: Service, tourism, distribution, miscellaneous.
The size variable was measured by the logarithm of total assets. The dependent variable, the financial debt ratio, is measured globally; it is the total of financial debts, which aggregates the short term, with the exception of commercial debt, and the long term, on the total balance sheet.

We have not reproduced all the results of the equation estimates here, so as not to make the discussion amphigoric and hieroglyphic. First, we included the coverage ratio, the degree of skewness, the growth rate, the size, the collateral and the substitution risk in a first equation. The positive sign of the estimated coefficient for the coverage ratio was then noted - the inclusion of this variable in the debt equation indicates that it does not represent a constraint but only the mechanical effect of an increase in debt. We can therefore conclude that the groups are not really constrained in terms of repayment capacity. On this point, it should be noted that other profitability variables were introduced: none of them proved to be significant. We therefore opted to exclude the coverage rate from the equations insofar as it expresses a mechanical link. The same applies to the growth rate, which is very erratic. Table 4 shows the results of the estimations incorporating only the remaining variables.

As expected, the coefficient of determination (adjusted $\mathrm{R}^{2}$ ) is relatively low, as the stock of debt in one year is the result of decisions in previous periods.

The following comments can be made about this results table:

1) The asymmetry variable is significantly estimated and its sign is consistent with the theoretical hypothesis: the greater the asymmetry, the more limited the debt ratio;

2) The guarantee variable is positively related to debt: this was the expected sign;

3) The substitution risk variable is negatively related to the debt ratio;

4) The estimated coefficient of the hierarchy variable is negative: it corresponds well to the idea of increasing indebtedness in inverse relation to the funds available after financing "usual" dividends and a fraction of "past" investments, i.e. the balance of internal financing available after allocation to information (dividends) and to internal investment opportunities.

5) On the other hand, the size variable is not significant.

Table 4. Explained variable (Financial debt)/(Balance sheet total) ${ }^{33}$.

\begin{tabular}{lll}
\hline Variable & Estimated coefficient & t-statistic \\
\hline Constant & 0,471 & 4,71 \\
Skewness & $-0,107$ & 6,65 \\
Size & $-0,011$ & 1,73 \\
Guarantee & 0,169 & 2,39 \\
Substitution & $-0,059$ & 2,14 \\
Hierarchy & $-0,769$ & 2,96 \\
Adjusted $\mathrm{R}^{2}=0,18$ Number & & Year: 2019 \\
\hline
\end{tabular}

33 The above estimates are obtained with the Ordinary Least Squares method after correcting for heteroscedasticity and reestimation of the variance-covariance matrix of the model parameters according to the Hansen method. The Student's't' in the tables take this into account. 
Therefore, leverage appears to be directly related to the ability to provide collateral with fixed assets and inversely related to substitution risk and the degree of skewness. On the other hand, size does not appear to explain the determination of the debt ratio of groups. From this first model, we can also see that the hypothesis of group overindebtedness can be rejected: the link between the "guarantee" and "rate" variables indicates an absence of illusion on the part of the group's external partners.

Moreover, sectoral affiliation seems to be linked to a component of indebtedness. The group's dominant sector of activity was chosen as the sector affiliation criterion. The share of variance explained by the sectors is, depending on the year, from 10 to $17 \%$ of the initial variance. It should be noted that sectors 2 (intermediate goods), 3 (capital goods production) and 6 (consumer goods) are the best estimated. It is easy to see that part of the explanation for the contribution of these sectors also lies in their asset structure. This can be shown by estimating the purely financial variables and the sectoral variables simultaneously. Table 5 shows the results with the variables from the previous equation in which we simply introduced the sector indicators.

Table 5. Explained variable (Financial debt)/(Balance sheet total).

\begin{tabular}{lll}
\hline Variable & Estimated coefficient & t-statistic \\
\hline Skewness & $-0,109$ & 4,92 \\
Size & $-0,018$ & 0,24 \\
Collateral & 0,019 & 0,23 \\
Substitution & $-0,078$ & 2,63 \\
Hierarchy & $-0,886$ & 3,60 \\
Sector 1 & 0,304 & 2,29 \\
Sector 2 & 0,396 & 3,56 \\
Sector 3 & 0,358 & 3,24 \\
Sector 4 & 0,509 & 3,92 \\
Sector 5 & 0,225 & 1,90 \\
Sector 6 & 0,409 & 3,77 \\
Sector 7 & 0,391 & 3,69 \\
Adjusted R ${ }^{2}=0,255$ Number of & & Year: 2019 \\
observations: 161 & & \\
\hline
\end{tabular}

Table 5, in which both industry and financial ratio information is introduced, shows a loss of explanatory power for the guaranteed variable. The importance of some sectors is also diminished. There is thus a common basis between the guarantee variable and some aspects measured by the sectoral variables. As for the other variables, they remain highly significant in terms of a link with the debt ratio.

The equation as reported explains about $26 \%$ of the variance in debt rates in 2019. But, it is important to note that the debt ratio in 2019 is explained by the level achieved in 2018 (correlation of 0.73 ) and 2017 (correlation of 0.87 ). It is the examination of these correlation coefficients that should be referred to when evaluating the coefficient of variance explained by the equation in Tables 4 and 5 above. Table 6 below shows the same variables as in Table 4, but with the previously achieved level of debt included as an explanatory variable; it is not possible to assume a considerable variation in levels from one year to the next, as the term of the debt prevents rapid adjustments (if the firm had the capacity to do so with annual results alone, which is difficult to imagine, as the financial debt of the groups represents an average of five full years of self-financing capacity).

Table 6. Explained variable (Financial debt)/(Balance sheet total).

\begin{tabular}{lll}
\hline Variable & Estimated coefficient & t-statistic \\
\hline Constant & 0,176 & 2,35 \\
Debt ratio 2018 & 0,719 & 13,79 \\
Skewness & $-0,043$ & 2,64 \\
Size & $-0,048$ & 0,97 \\
Collateral & 0,012 & 0,23 \\
Substitution & $-0,003$ & 0,16 \\
Hierarchy & $-0,451$ & 2,67 \\
Adjusted $\mathrm{R}^{2}=0,63$ Number of & & Year: 2019 \\
observations: 161 & & \\
\hline
\end{tabular}

The share of variance explained reaches $63 \%$ this time, with the coefficient on lagged debt being close to the correlation coefficient of the 2019 and 2018 debt rates. The skewness and hierarchy variables remain significant while the collateral and substitution variables do not. It is likely that the debt of the previous period "incorporates" these effects to some extent.

\section{Conclusion}

Whether the results are shown in Tables 4 or 5 , the determination of group debt levels measured with the help of consolidated accounts seems to be in line with some of the theoretical assumptions made in the second section. However, it should be noted that the profitability variables are not significant. Above all, the most significant variables appear to be those justifying debt by information asymmetry and the financing hierarchy. The sign of the latter variable does not seem to support the hypothesis of Jensen's free cash flows in relation to the evolution of debt.

The contribution of new equity seems low over the period, since on average over three years it represents about $10 \%$ of the financing resources of the groups in the sample. Over the same period, the level of debt has decreased slightly. In addition to the size of the sample or the insufficient number of years, a few reservations may qualify some of these results. First, we note the diversity of consolidation practices: while this diversity may have little influence on the measurement of debt, it may partly influence our results with the profitability variables. Secondly, it would be important to look for more diversified sources of information than the accounting sources, given the precision of the theoretical hypotheses to be tested; for example, data on the distribution of capital, levels of risk with finer assessments of the different activities and taking into account market volatilities for listed companies. Similarly, the collection of information on the fraction of listed debt, market reactions to issues, and the terms of recourse to commercial paper should also be included. This is a sort of agenda of desirable future research. 


\section{References}

[1] AMAR M. and THOLLON-POMMEROL V., 1989, "Les groupes et la déformation du système productif français 1974 1980-1986", INSEF - Journées Centrales des bilans 1989, 61 pages.

[2] ANGELO (de) H. and MASULIS R., 1980, "Optimal Capital Structure under Corporate and Personal Taxation", Journal of Financial Economics, March, pp. 3-29.

[3] BATSCH L., 1992, "Aspects financiers et stratégiques des politiques de recentrage des groupes industriels en France", Doctoral thesis from the University of Paris-Dauphine.

[4] BEAU D., 1990, "Les influences de l'appartenance à un groupe sur les structures et les résultats des entreprises industrielles françaises", Analyse financière, 4th quarter.

[5] BIAIS B., HILLION P. and MALECOT J. F., 1991, "The Capital Structure of French Corporation: an empirical investigation", International Capital Structure symposium UCLA, July, 34 p.

[6] Brounen D., Jong (de) A., Koedijk K., "Corporate Finance in Europe: confronting theory with practice", Financial Management, vol. 33, n4, 2004, pp. 167-184.

[7] Chadefaux M., Les fusions des sociétés: Régimes juridiques et fiscal, 8th edition, Groupe Revue Fiduciaire, 2016.

[8] Cathiard C. Lecourt A., La pratique du droit européen des sociétés. Comparative analysis of cross-border structures and mergers, Joly Editions, 2nd edition, 2017.

[9] CHARASSON-JASSON Hélène, "the growing recourse of large French groups to debt: a financing strategy that shows its limits, Bulletin de la Banque de France n²26-4, November 2019.

[10] Chava S., Purnanandam A., "Determinant of the floating-tofixed rate debt structure of firms", Journal of Financial Economics, vol. 85, $\mathrm{n}^{\circ}$ 3, September 2007, pp 5-18.

[11] COMMISSION DES OPERATIONS DE BOURSE, 1991, 1992, "Rapports au Président de la République".

[12] DIETSCH M., JACQUILLAT B. ET PIETRI R., 1986, Le crédit interentreprises: un financement de troisième type, Publication de l'Institut La Boétie, 38 p.

[13] Denis D., Mihov V., "The Choice among bank debt, non-bank private debt and public debt: evidence form new corporate barrowings", Journal of Financial Economics, January 2003, $\mathrm{n}^{\circ} 1$, vol. 70, pp 3-28.

[14] DIETSCH M., 1990, "Le crédit interentreprises: coûts et avantages", Economie et Statistique, pp. 65-79.

[15] DUBOIS M., 1985, "Les déterminants de la structure financière des entreprises", Finance, p. 41-70.

[16] FAZZARI S., HUBBARD R. G. and PETERSEN B. C., 1988, "Financing constraints and corporate investment", Brookings papers on economic activity, p. 141-206.

[17] Fernandez P., Évaluation et bon sens, 7e édition, 2019 à télécharger sur ssrn.com.

[18] HARRIS M. et RAVIV A., 1991, "The theory of capital structure", Journal of Finance, mars, p. 297-355.
[19] HARRIS M. et RAVIV A., 1990, "Capital structure and the informational role of debt", Journal of Finance, June, p. 321349 .

[20] HAUGEN R. A. et SEMBET L. W., 1978, "The insignificance of bankruptcy costs to the theory of optimal capital structure", Journal of Finance, p. 383-349.

[21] Hege U., Lovo S., Slovin M., " Equity and cash in intercorporate asset sales: theory and evidence ", Review of Financial Studies, february 2009, vol. 22, n², pp. 681-714.

[22] Holland D., "An improved method for valuing mature companies and estimating terminal value ", Journal of Applied Corporate Finance, vol. 30, n ${ }^{\circ}$, 2018, pp. 70-77.

[23] JENSEN M. et MECKLING W. H., 1976, "Theory of the firm, managerial behavior, agency costs and ownership structure", Journal of Financial Economics, n³, p. 305360 .

[24] LAET (DE) J. P., 1991, "Le contrôle communautaire des concentrations", Notes et Etudes Documentaires, $n^{\circ}$ 4926, pp 161- 170, Documentation Française.

[25] Krishaswami S., Subramaniam V., "information asymmetry, valuation and corporate spin-off decision", Journal of Financial Economics, vol. 53, n¹, 1999, pp. 73-112.

[26] Lonnidou V., Ongena S., "Time for a change: loan conditions and bank behavior when firms switch banks", Journal of Finance, octobre 2010, vol. 65, n5, pp. 1847-1877.

[27] MALECOT J. F., 1991, "Les déterminants du choix d'une structure financière: le cas des groupes industriels et commerciaux", Caisse des Dépôts /COREF, Journées centrales des bilans, $50 \mathrm{p}$.

[28] MALECOT J. F., 1992 a, "Liquidation, Redressement judiciaires et taux de recouvrement des créances", Cahier du CEREG, $n^{\circ} 9205$.

[29] MALECOT J. F., 1992 b. "Comptes consolidés et situation financière des groupes industriels et commerciaux", Cahier du CEREG, $n^{\circ} 9203$.

[30] MALECOT J. F., 1992 c, "Les déterminants du choix d'une structure financière des groupes industriels et commerciaux", Cahier de Recherches du CEREG, ${ }^{\circ} 9212$.

[31] MALECOT J. F., 1992 d, "Modelling behavioral dividend policy using company account panel data" - in Econometrics of panel data, Kluwer L., Mathyas P., Sevestre éditeurs.

[32] MILLER M. H., 1988, "The Modigliani-Miller propositions after thirty years", Journal of Economic Perspectives, 2, p. 99-120.

[33] M0RIN F., 1991, "L'émergence d'un appareil productif européen". Notes et Etudes Documentaires, p. 17-36.

[34] MYERS S. C. et MAJLUF, 1984, "Corporate financing and investment decisions when firms have information that investors do not have", Journal of Financial Economics, p. $187-221$.

[35] OHANA K., 1990, Les banques de groupe, PUF.

[36] PAULET Elisabeth, " La structure financière des entreprises en Europe: une investigation empirique de la neutralité du bilan, dans Economie et Prévisions, $n^{\circ} 157$, volume 1, 2003, p. 71-82. 
[37] REMOLONA E. M., 1990, "Understanding international differences in leverage trends", Federal Reserve Bank of New York Quarterly Review, Spring, p. 31-42.

[38] RICHARD J., SIMONS P. et BAILLY J. M., 1988, Comptabilité et analyse financière des groupes, Economica.

[39] Robert Obert, Le Petit IFRS 2020, Dunod, 11e édition, février 2020.
[40] THOLLON-POMMEROL V., 1990, "Les groupes et la déformation du système productif", Economie et statistique, février, p. 21-28.

[41] TITMAN S., 1984, "The effect of capital structure on a firm's liquidation decision", Journal of Financial Economics, 13, p. 137-151.

[42] Vernimmen P., Finance d'entreprise, Dalloz, 19e édition, 2021, 1198 pages. 